\title{
Pengembangan Perangkat Pembelajaran Gerak Dasar Lempar Berbasis Aplikasi Articulate Storyline
}

\author{
Yofandre Putra Wintoro*, Lokananta Teguh Hari Wiguno, Ari Wibowo Kurniawan, \\ Mu'arifin \\ Universitas Negeri Malang, Jl. Semarang No. 5 Malang, Jawa Timur, Indonesia \\ *Penulis korespondensi, Surel: andreayofan11@gmail.com
}

Paper received: 17-6-2021; revised: 1-7-2021; accepted: 8-7-2021

\begin{abstract}
The purpose of research and development is to develop a basic motion learning tool of throwing in the form of an application articulate storyline for the PJOK Primary School Teacher Working Group (KKG) in Wajak District, Malang Regency so that it becomes one of the new knowledge in developing learning media. The method used is approach Research and Development with a development model that has been developed from the product development. The results obtained in small group trials 86 percent research is stated to help in learning and large group trials 84 percent research is stated to help in learning, so it is concluded that the product development of volleyball learning materials based on the application articulate storyline has very valid criteria and is suitable for use in learning activities.
\end{abstract}

Keywords: basic throwing movement; articulate storyline application; learning tools

\begin{abstract}
Abstrak
Tujuan dari penelitian dan pengembangan untuk mengembangkan perangkat pembelajaran gerak dasar lempar berbentuk aplikasi articulate storyline untuk Kelompok Kerja Guru (KKG) PJOK Sekolah Dasar di Kecamatan Wajak Kabupaten Malang sehingga menjadi salah satu pengetahuan baru dalam mengembangkan media pembelajaran. Metode yang digunakan yaitu pendekatan Research and Development dengan model pengembangan yang telah dilakukan dari pengembangan. Produk tersebut memperoleh hasil pada uji coba kelompok kecil 86 persen penelitian dinyatakan membantu dalam pembelajaran dan uji coba kelompok besar 84 persen penelitian dinyatakan membantu dalam pembelajaran, sehingga disimpulkan bahwa produk pengembangan perangkat pembelajaran materi gerak dasar lempar berbasis aplikasi articulate storyline memiliki kriteria sangat valid serta layak dipakai pada kegiatan pembelajaran.
\end{abstract}

Kata kunci: gerak dasar lempar; aplikasi articulate storyline; perangkat pembelajaran

\section{Pendahuluan}

Di era teknologi seperti saat ini guru harus dituntun bisa semaksimal mungkin untuk mengelola kegiatan kelas secara baik dan efektif. Selain itu guru juga harus bisa menumbuhkan hubungan yang baik terhadap peserta didik dan komunitas sekolah dengan teknologi pendukung. Dengan satu tujuan untuk mempermudah peserta didik dan memajukan mutu pendidikan yang lebih bagus seiring dengan kemajuan zaman. Kondisi ini memaksa seorang pendidik atau guru penjas di sekolah untuk benar-benar menganalisis masalah yang terjadi pada proses pembelajaran (Mislan \& Santoso, 2019). Menurut Kartowagiran (2015), Guru profesional memiliki tugas utama mendidik, mengajar, membimbing, mengarahkan, melatih, menilai, dan mengevaluasi peserta didik pada pendidikan anak usia dini jalur pendidikan formal, pendidikan dasar, dan pendidikan menengah. Dalam melaksanakan tugasnya, guru menerapkan keahlian, kemahiran yang memenuhi standar mutu atau norma tertentu yang diperolehnya melalui pendidikan profesi. Pemerintah mengupayakan dalam meningkatkan 
mutu dan profesionalitas guru pendidikan di era teknologi seperti saat ini, Akan tetapi usaha yang telah pemerintah lakukan dalam meningkatkan mutu dan profesionalitas guru terbilang belum efektif dikarenakan masih terdapat guru-guru yang tidak paham akan teknologi pembelajaran, terlebih guru-guru yang sudah lama mengabdi sehingga dalam pembaharuan sistem kegiatan pembelajaran belum dapat dilakukan, mengikuti era teknologi saat ini.

Pendidikan Jasmani adalah mata pelajaran yang memberikan pengaruh terhadap kegiatan pembelajaran di sekolah, selain meningkatkan kemampuan pengetahuan, pendidikan jasmani dapat meningkatkan sikap dan psikomotorik peserta didik. Menurut Mustafa, \& Dwiyogo, (2020), menjelaskan bahwa pendidikan jasmani merupakan bagian dari pendidikan yang mengembangkan kemampuan melalui gerak sehingga dapat mencapai kesehatan serta tujuan pendidikan yang diharapkan yaitu mencakup pengetahuan, keterampilan, dan sikap. Dengan demikian guru penjas perlu memahami tujuan dari pendidikan jasmani agar pembelajaran gerak menjadi berkembang sesuai dengan target yang dicapai. Oleh karena itu dapat disimpulkan bahwa pendidikan jasmani merupakan proses pendidikan yang lebih berfokus kepada aktivitas fisik, gerak dan emosional peserta didik. Pendidikan jasmani adalah pelajaran yang telah disusun secara terstruktur, terarah serta terencana melalui kegiatan pembelajaran yang terdapat, afektif, kognitif dan psikomotorik dengan tujuan mengembangkan pengetahuan dan keterampilan peserta didik secara keseluruhan. Menurut Mylsidayu (2014), pendidikan jasmani merupakan proses pembelajaran yang menggunakan aktivitas jasmani atau fisik yang meliputi psikomotor, kognitif, dan afektif. Menurut Mashudi \& Nurrochmah, (2020) Pendidikan jasmani olahraga dan kesehatan juga bertujuan untuk meningkatkan kemampuan gerak dasar yang dimiliki oleh anak-anak. Kemampuan keterampilan gerak dasar merupakan sebuah kemampuan yang sangat penting di dalam kehidupan sehari-hari maupun dalam pendidikan jasmani olahraga dan kesehatan. Salah satu pemberian program pendidikan jasmani olahraga dan kesehatan kepada anak-anak adalah agar menjadi terampil dalam melakukan aktifitas fisik

Pada materi pendidikan jasmani terdapat materi gerak dasar lempar, peserta didik harus memahami materi pembelajaran gerak dasar lempar dan dapat mempraktikkannya dengan baik benar. Menurut Wiarto, (2015), pendidikan jasmani adalah pendidikan yang tersusun secara sistematis dan terarah serta terencana melalui aktivitas pembelajaran yang didalamnya memiliki unsur-unsur kognitif, afektif dan psikomotor dengan tujuan untuk meningkatkan pengetahuan individu secara utuh. Sedangkan menurut Akhmad, (2016), menyatakan bahwa pendidikan jasmani merupakan proses pendidikan dimana individu dapat meningkatkan dan mengalami perubahan diri yang meliputi fisik mental dan emosional. Oleh karena itu, dapat disimpulkan bahwa pendidikan jasmani merupakan proses pembelajaran dalam sebuah pendidikan yang disusun secara sistematis dan terencana agar individu dapat mengalami perubahan diri dalam meningkatkan pengetahuan yang meliputi unsur kognitif, afektif dan psikomotor. Hal ini dikarenakan materi gerak dasar melempar terdapat dalam kompetensi kognitif dan psikomotorik yang dirumuskan dalam Kompetensi Inti (KI) dan Kompetensi Dasar (KD) yang diajarkan di jenjang Sekolah Dasar (SD) kelas IV. Perkembangan teknologi yang semakin pesat tentunya berdampak bagi pendidikan di Indonesia, sebab aktivitas olahraga termasuk dalam sistem pendidikan, yaitu mata pelajaran PJOK. Di zaman yang modern seperti sekarang guru memiliki peranan penting dalam meningkatkan kreatifitas dalam mengembangakan media pembelajaran, sehingga perlu pembinaan yang sesuai untuk meningkatkan profesionalitas guru dalam menyelenggarakan pembelajaran. 
Media pembelajaran merupakan sarana penyampaian pesan pembelajaran kaitannya dengan model pembelajaran langsung yaitu dengan cara guru berperan sebagai penyampai informasi dan dalam hal ini guru seyogyanya menggunakan berbagai media yang sesuai. Menurut Kurniawan dan Tangkudung (2017), berpendapat bahwa saat ini multimedia interaktif merupakan multimedia yang sangat diakui sebagai salah satu cara untuk dapat memecahkan suatu masalah pendidikan yang terjadi di negara maju dan juga di negara berkembang. Menurut Larsson, \& Karlefors, (2015), mengemukakan bahwa guru bukan satusatunya sumber belajar, sebab menjadi seorang guru harus memiliki strategi pembelajaran yang akan membantu siswa untuk memahami kegiatan pendidikan salah satunya mengembangkan media pembelajaran. Selain itu seiring berkembangnya waktu, kemajuan teknologi sangatlah cepat bahkan bisa dibilang sangat pesat, tentunya dengan kondisi seperti ini seorang guru diharapkan dapat memanfaatkan kemajuan teknologi dengan menggunakan multimedia interaktif dalam proses pembelajaran. Menurut Mcneil, (2015), menyatakan bahwa sebuah media pembelajaran bisa mempermudah siswa saat memahami suatu informasi agar siswa mudah untuk menguasai keterampilan yang akan dipelajarinya.

Articulate storyline adalah sebuah perangkat lunak atau software e-learning yang berfungsi untuk membuat media perangkat pembelajaran yang interaktif, fungsi articulate storyline sama dengan microsoft powerpoint. Articulate storyline merupakan alat yang digunakan untuk mempresentasikan informasi dengan tujuan tertentu Menurut Nugraheni (2017), dengan media pembelajaran, siswa dapat memahami materi sangat jelas karena materi yang digunakan yaitu teks, gambar, animasi, audio, dan video. Articulate Storyline bisa membuat kelas yang menyenangkan dan dapat mengajak siswa untuk aktif dalam pembelajaran sebab materi dilengkapi kuis yang dapat langsung dikerjakan dan tanpa menunggu koreksi jawaban dari guru dan nilai akan otomatis muncul dari sistem. Menurut Akbar \& Hariyanto, (2020) Bahan ajar memiliki peran dan fungsi yang sangat strategis bagi proses pembelajaran yang dapat membantu guru dan siswa dalam kegiatan pembelajaran. Bahan ajar dapat menggantikan sebagian peran guru dan mendukung pembelajaran individual, dan juga dapat memberikan dampak positif bagi guru, karena sebagian waktunya dapat dicurahkan untuk membimbing belajar siswa.

Berdasarkan hasil penelitian sebelumnya terdapat keunggulan dari produk pengembangan articulate storyline yaitu dengan menggunakan Rencana Pelaksanaan Pembelajaran (RPP) gerak dasar lempar, materi pembelajaran gerak dasar lempar, video materi atau praktek pembelajaran gerak dasar lempar kelas IV, dan evaluasi pembelajaran gerak dasar lempar, bisa diakses melalui link dan bisa diunduh sebagai aplikasi android. Jika menggunakan komputer bisa diakses melalui link yang diberikan, sehingga memudahkan dan menjadi referensi mengajar guru mata pelajaran PJOK khususnya Sekolah Dasar (SD) dalam menyelenggarakan pembelajaran gerak dasar lempar. Produk ini juga dapat digunakan jika sarana dan prasarana pembelajaran gerak dasar lempar tidak memadai, serta dapat digunakan di dalam kelas sebelum praktek dilapangan. Selain itu, dengan adanya produk pengembangan ini diharapkan dalam proses pembelajaran guru bisa mendapat perhatian siswa. Melalui pengembangan produk diharapkan dapat memotivasi siswa, sehingga pembelajaran gerak dasar lempar lebih efektif dan efisien. Aplikasi articulate storyline merupakan perangkat lunak untuk difungsikan sebagai alat komunikasi atau sebagai perantara presentasi yang memiliki fitur-fitur untuk memasukkan gambar, video, animasi, audio, dan lainnya yang dapat diakses secara online dan offline (Purnama, \& Asto, 2014). 
Hasil analisis kebutuhan sebagai observasi awal penelitian di Kecamatan Wajak, Kabupaten Malang, analisis kebutuhan yang dilakukan oleh peneliti dengan menyebar angket menggunakan google form melalui ketua dan wakil ketua KKG, diperoleh hasil bahwa pembelajaran gerak dasar lempar untuk jenjang Sekolah Dasar (SD) di Kecamatan wajak masih monoton dan proses pembelajaran belum memanfaatkan teknologi, sedangkan perangkat pembelajaran hanya menggunakan print out dan LKS. Hal tersebut merupakan perangkat pembelajaran yang telah lama, selain itu belum adanya pengembangan perangkat pembelajaran gerak dasar lempar berbasis aplikasi articulate storyline. Padahal fasilitas yang ada di setiap sekolah sudah memiliki alat penunjang seperti LCD, smartphone dan komputer untuk pembelajaran.

\section{Metode}

Metode penelitian pengembangan berpatokan kepada model pengembangan Lee dan Owen (2004), dengan cara sebagai berikut: (1) mengerjakan needs assessment atau analisis kebutuhan, (2) mengerjakan design atau desain produk, (3) development atau mengembangkan produk, (4) implementation atau pengerjaan, dan (5) evaluation atau evaluasi produk. Prosedur tersebut digunakan sebagai sebuah langkah untuk memecahkan permasalahan, menciptakan bahkan mengembangkan menjadi suatu produk. Oleh karena itu peneliti, menggunakan serangkaian penelitian pengembangan ini agar menciptakan dan menyusun suatu produk perangkat pembelajaran materi gerak dasar lempar berbasis aplikasi articulate storyline.

Prosedur uji coba produk dilaksanakan untuk mencari serta mendapatkan data mentah untuk dipakai sebagai dasar untuk menentukan suatu kepantasan produk telah dikembangkan. Terdapat beberapa perhatian pada uji coba produk, antara lain: (1) desain uji coba, (2) menentukan subjek uji coba, (3) jenis data, (4) menyusun instrumen, (5) teknik analisis data. Pada tahapan desain uji coba, peneliti akan memperbaiki produk sesuai saran dan masukan dari ahli PJOK, ahli pembelajaran, ahli permainan SD, ahli media, ahli gerak dasar lempar serta uji coba kelompok. Dalam uji coba kelompok kecil berjumlah 8 guru, untuk uji coba kelompok besar berjumlah 15 guru, nantinya setelah peneliti mengumpulkan semua data dari para ahli yang diperlukan sebagai masukan untuk memperbaharui produk yang telah dirancang peneliti. Data yang diperoleh dari penelitian berupa data kualitatif dan kuantitatif, dimana data kualitatif di dapat pada saran dan masukan ahli data kuantitatif di dapat hasil dari uji coba kelompok kecil dan uji coba kelompok besar yang berupa pengisian angket. Dan teknik analisis menggunakan statistik deskriptif menggunakan persentase, sedangkan teknik pengukurannya menggunakan skala likert.

Tabel 1. Penilaian Skala untuk Pernyataan Positif

\begin{tabular}{clcc}
\hline No. & Keterangan & Jawaban & Skor Positif \\
\hline 1. & Sangat Setuju & $\mathrm{A}$ & 4 \\
2. & Setuju & $\mathrm{B}$ & 3 \\
3. & Ragu-ragu & $\mathrm{C}$ & 2 \\
4. & Tidak Setuju & $\mathrm{D}$ & 1 \\
\hline
\end{tabular}

Rumus yang digunakan untuk mengolah data berupa analisis deskriptif kuntitatif persentase sebagai berikut: 
$V=\frac{T S E V}{S-\max } \times 100 \%$

Keterangan:

V : Validitas

TSEV : Total skor empirik validator

S-max : Skor maksimal yang diharapkan

100\% : Bilangan konstanta

Agar mempermudah dalam proses penyimpulkan data dari hasil analisis persentase dapat digolongkan sesuai dengan persentase yang telah dianalisis penggolongan persentase sebagai berikut:

Tabel 2. Kriteria Kualitas Produk

\begin{tabular}{ccc}
\hline Kriteria & Keterangan & Makna \\
\hline $75,01 \%-100,00 \%$ & Sangat Valid & Digunakan tanpa revisi \\
$50,01 \%-75,00 \%$ & Cukup Valid & Digunakan dengan revisi kecil \\
$25,01 \%-50,00 \%$ & Tidak Valid & Tidak dapat digunakan \\
$00,00 \%-25,00 \%$ & Sangat Tidak Valid & Terlarang digunakan \\
\hline
\end{tabular}

\section{Hasil dan Pembahasan}

\subsection{Hasil}

Hasil penelitian dalam artikel ini memaparkan mengenai analisis data yang berasal dari beberapa ahli atau pakar diantaranya pakar pembelajaran, pakar permainan sekolah dasar, pakar pendidikan jasmani olahraga dan kesehatan, ahli media, ahli atletik, dan hasil data uji coba dari kelompok kecil maupun kelompok besar. Hasil dari analisis data yang dikumpulkan mengacu pada segi ketepatan, kejelasan, dan kemudahan dari produk pengembangan perangkat pembelajaran gerak dasar lempar berbasis aplikasi articulate storyline dan disajikan dibawah:

Tabel 3. Hasil Data Analisis Ahli Pembelajaran

\begin{tabular}{cccc}
\hline No. & \multicolumn{1}{c}{ Aspek } & $\mathbf{\%}$ & Kategori \\
\hline 1 & Kejelasan & 85 & Sangat Valid \\
2 & Ketepatan & 75 & Cukup Valid \\
3 & Kemudahan & 100 & Sangat Valid \\
\hline & Rata-Rata & $\mathbf{8 7}$ & Sangat Valid \\
\hline
\end{tabular}

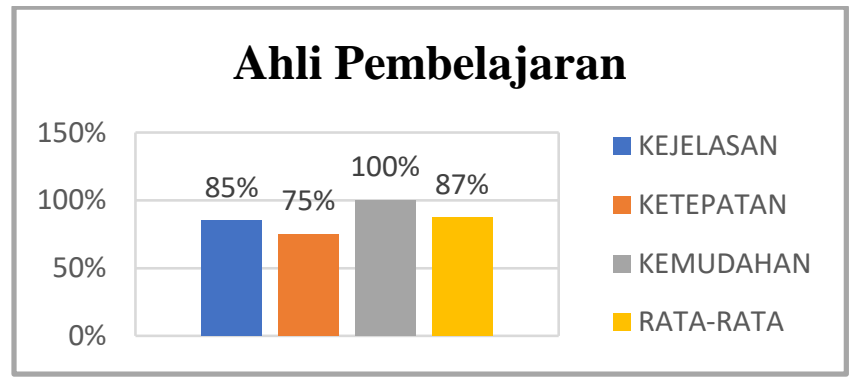

Gambar 1. Diagram Persentase Penilaian Ahli Pembelajaran pada Produk Pengembangan Perangkat Pembelajaran Gerak dasar lempar Berbasis Aplikasi Articulate Storyline. 
Berdasarkan hasil analisis data yang diperoleh dari uji validasi oleh ahli pembelajaran dengan persentase sebesar 87\%, hasil tersebut didapatkan dari aspek-aspek yang kemudian hasil tersebut dikonversikan berdasarkan tabel klasifikasi kelayakan menunjukkan bahwa produk pengembangan perangkat pembelajaran gerak dasar lempar berbasis aplikasi articulate storyline telah memenuhi kriteria sangat valid dan layak digunakan untuk melanjutkan uji coba kelompok.

Mengacu pada segi kejelasan, ketepatan, kemudahan, kemenarikan serta kesesuaian, sehingga didapatkan analisis data yang dipaparkan melalui produk pengembangan perangkat pembelajaran gerak dasar lempar berbasis aplikasi articulate storyline dan disajikan di bawah:

Tabel 4. Hasil Data Analisis Ahli Permainan Sekolah Dasar

\begin{tabular}{clrc}
\hline No. & \multicolumn{1}{c}{ Aspek } & \% & Kategori \\
\hline 1 & Kejelasan & 87 & Sangat Valid \\
2 & Kemudahan & 75 & Cukup Valid \\
3 & Kemenarikan & 100 & Sangat Valid \\
4 & Kesesuaian & 75 & Cukup Valid \\
5 & Ketepatan & 94 & Sangat Valid \\
\hline & Rata-Rata & $\mathbf{8 6}$ & Sangat Valid \\
\hline
\end{tabular}

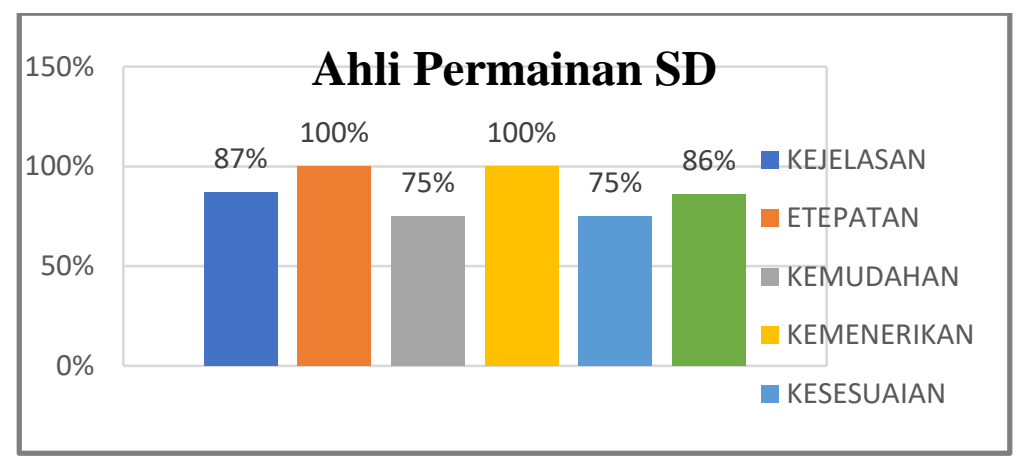

Gambar 2. Diagram Persentase Penilaian Ahli Permainan Sekolah Dasar pada Produk Pengembangan Perangkat Pembelajaran Gerak dasar lempar Berbasis Aplikasi Articulate Storyline.

Berdasarkan hasil analisis data yang diperoleh dari uji validasi oleh ahli permainan Sekolah Dasar dengan persentase sebesar 86\%, hasil tersebut didapatkan dari aspek-aspek yang kemudian hasil tersebut dikonversikan berdasarkan tabel klasifikasi kelayakan menunjukkan bahwa produk pengembangan perangkat pembelajaran gerak dasar lempar berbasis aplikasi articulate storyline telah memenuhi kriteria sangat valid dan layak digunakan untuk melanjutkan uji coba kelompok.

Mengacu pada segi kejelasan, ketepatan, kemudahan, kemenarikan serta kesesuaian, sehingga didapatkan analisis data yang dipaparkan melalui produk pengembangan perangkat pembelajaran gerak dasar lempar berbasis aplikasi articulate storyline dan disajikan di bawah: 
Tabel 5. Hasil Data Analisis Ahli PJOK

\begin{tabular}{clcc}
\hline No. & \multicolumn{1}{c}{ Aspek } & \% & Kategori \\
\hline 1 & Kejelasan & 82 & Sangat Valid \\
2 & Kemudahan & 75 & Cukup Valid \\
3 & Kemenarikan & 100 & Sangat Valid \\
4 & Kesesuaian & 75 & Cukup Valid \\
5 & Ketepatan & 81 & Sangat Valid \\
\hline \multicolumn{2}{l}{ Rata-Rata } & $\mathbf{8 3}$ & Sangat Valid \\
\hline
\end{tabular}

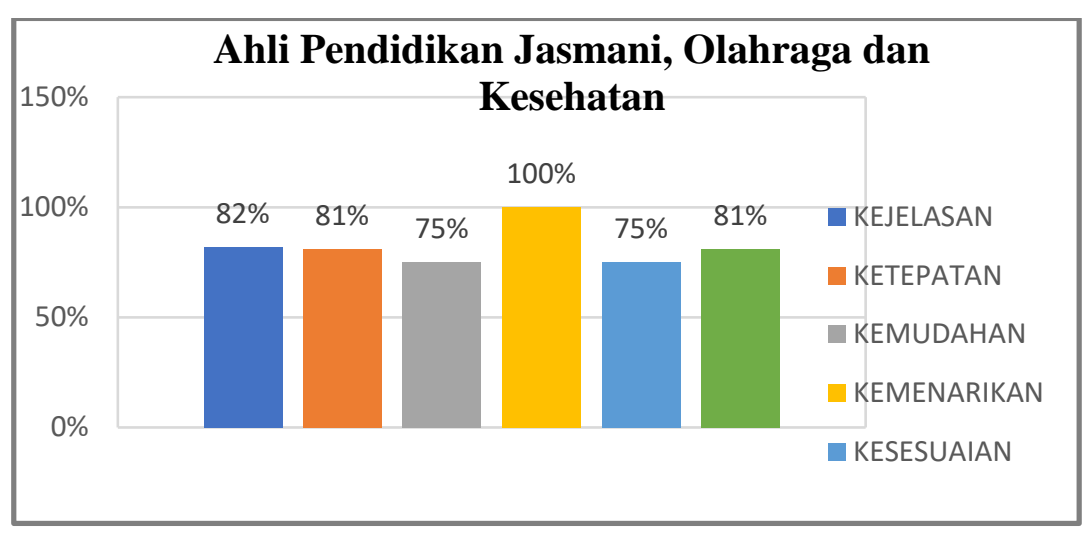

Gambar 3. Diagram Persentase Penilaian Ahli Pendidikan Jasmani, Olahraga dan Kesehatan pada Produk Pengembangan Perangkat Pembelajaran Gerak dasar lempar Berbasis Aplikasi Articulate Storyline

Berdasarkan hasil analisis data yang diperoleh dari uji validasi oleh ahli Pendidikan Jasmani, Olahraga dan Kesehatan dengan persentase sebesar 83\%, hasil tersebut didapatkan dari aspek-aspek yang kemudian hasil tersebut dikonversikan berdasarkan tabel klasifikasi kelayakan menunjukkan bahwa produk pengembangan perangkat pembelajaran gerak dasar lempar berbasis aplikasi articulate storyline telah memenuhi kriteria sangat valid dan layak digunakan untuk melanjutkan uji coba kelompok.

Mengacu pada segi kejelasan, kelengkapan, ketepatan, kemudahan, kemenarikan serta kesesuaian, sehingga didapatkan analisis data yang dipaparkan melalui produk pengembangan perangkat pembelajaran gerak dasar lempar berbasis aplikasi articulate storyline dan disajikan di bawah:

Tabel 6. Hasil Data Analisis Ahli Media

\begin{tabular}{clcc}
\hline No. & \multicolumn{1}{c}{ Aspek } & \% & Kategori \\
\hline 1 & Kejelasan & 100 & Sangat Valid \\
2 & Kelengkapan & 92 & Sangat Valid \\
3 & Kemudahan & 95 & Sangat Valid \\
4 & Kemenarikan & 100 & Sangat Valid \\
5 & Kesesuaian & 100 & Sangat Valid \\
6 & Ketepatan & 87 & Sangat Valid \\
\hline & Rata-Rata & $\mathbf{9 6}$ & Sangat Valid \\
\hline
\end{tabular}




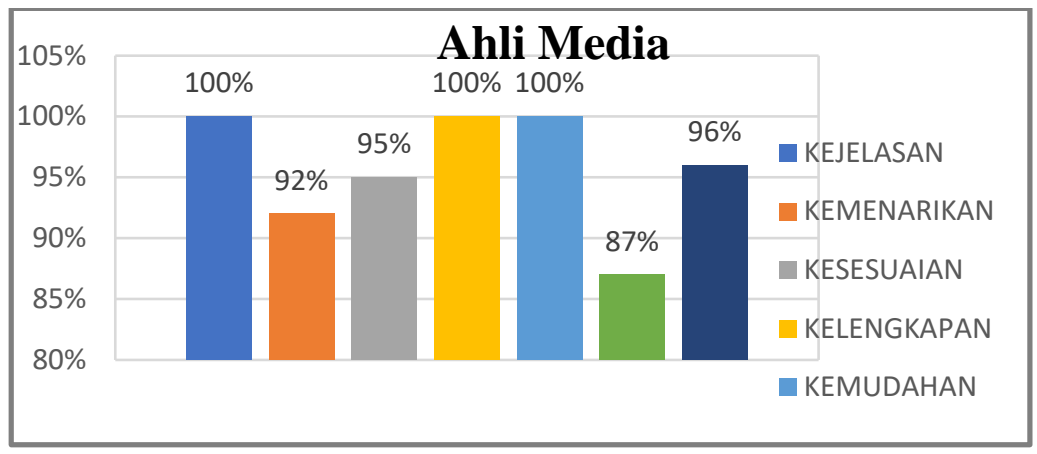

\section{Gambar 4. Diagram Persentase Penilaian Ahli Media pada Produk Pengembangan Perangkat Pembelajaran Gerak dasar lempar Berbasis Aplikasi Articulate Storyline}

Berdasarkan hasil analisis data yang diperoleh dari uji validasi oleh ahli media dengan persentase sebesar 96\%, hasil tersebut didapatkan dari aspek-aspek yang kemudian hasil tersebut dikonversikan berdasarkan tabel klasifikasi kelayakan menunjukkan bahwa produk pengembangan perangkat pembelajaran gerak dasar lempar berbasis aplikasi articulate storyline telah memenuhi kriteria sangat valid dan layak digunakan untuk melanjutkan uji coba kelompok.

Mengacu pada segi kejelasan, ketepatan, kemudahan, kemenarikan serta kesesuaian, sehingga didapatkan analisis data yang dipaparkan melalui produk pengembangan perangkat pembelajaran gerak dasar lempar berbasis aplikasi articulate storyline dan disajikan di bawah:

\section{Tabel 7. Hasil Data Analisis Ahli Atletik}

\begin{tabular}{clcc}
\hline No. & \multicolumn{1}{c}{ Aspek } & \% & Kategori \\
\hline 1 & Kejelasan & 89 & Sangat Valid \\
2 & Kemudahan & 100 & Sangat Valid \\
3 & Kemenarikan & 100 & Sangat Valid \\
4 & Kesesuaian & 79 & Sangat Valid \\
5 & Ketepatan & 100 & Sangat Valid \\
\hline & Rata-Rata & $\mathbf{9 4}$ & Sangat Valid \\
\hline
\end{tabular}

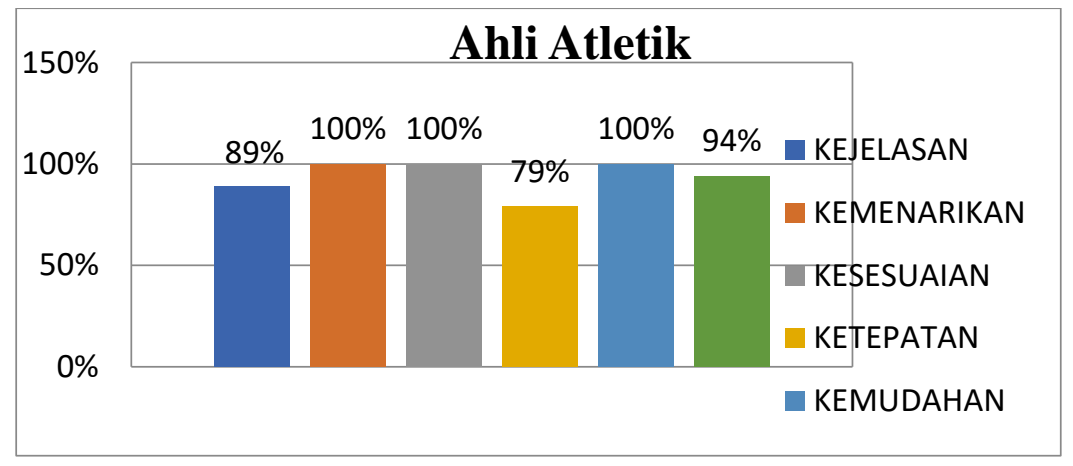

Gambar 5. Diagram Persentase Penilaian Ahli Atletik pada Produk Pengembangan Perangkat Pembelajaran Gerak dasar lempar Berbasis Aplikasi Articulate Storyline. 
Berdasarkan hasil analisis data yang diperoleh dari uji validasi oleh ahli atletik dengan persentase sebesar 94\%, hasil tersebut didapatkan dari aspek-aspek yang kemudian hasil tersebut dikonversikan berdasarkan tabel klasifikasi kelayakan menunjukkan bahwa produk pengembangan perangkat pembelajaran gerak dasar lempar berbasis aplikasi articulate storyline telah memenuhi kriteria sangat valid dan layak digunakan untuk melanjutkan uji coba kelompok.

Hasil data dari uji kelompok kecil mengacu pada segi kejelasan, kegunaan, kemudahan, kemenarikan serta kesesuaian, sehingga didapatkan analisis data yang dipaparkan melalui produk pengembangan perangkat pembelajaran gerak dasar lempar berbasis aplikasi articulate storyline dan disajikan di bawah:

Tabel 8. Hasil Data Analisis Uji Kelompok Kecil Kelompok Kerja Guru (KKG) PJOK SD

\begin{tabular}{clrc}
\hline No. & \multicolumn{1}{c}{ Aspek } & \% & Kategori \\
\hline 1 & Kejelasan & 86 & Sangat Valid \\
2 & Kemudahan & 84 & Sangat Valid \\
3 & Kemenarikan & 84 & Sangat Valid \\
4 & Kesesuaian & 84 & Sangat Valid \\
5 & Kegunaan & 94 & Sangat Valid \\
\hline & Rata-Rata & $\mathbf{8 6}$ & Sangat Valid \\
\hline
\end{tabular}

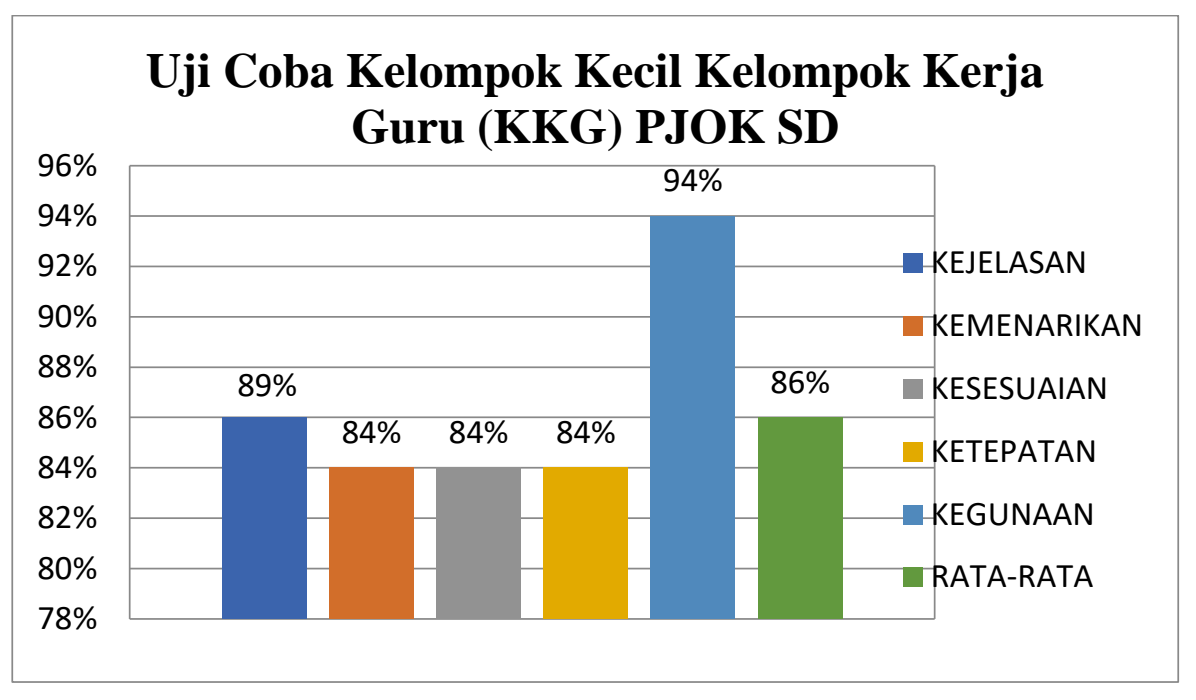

Gambar 6. Diagram Persentase Hasil Data Uji Kelompok Kecil Kelompok Kerja Guru (KKG)

Berdasarkan hasil analisis data yang diperoleh dari uji coba kelompok kecil oleh Kelompok Kerja Guru (KKG) PJOK SD di Kecamatan Wajak, Kabupaten Malang dengan persentase sebesar 86\%, hasil tersebut didapatkan berdasarkan aspek-aspek kemudian hasil tersebut dikonversikan berdasarkan tabel klasifikasi kelayakan menunjukkan bahwa produk pengembangan perangkat pembelajaran gerak dasar lempar berbasis aplikasi articulate storyline telah memenuhi kriteria sangat valid dan layak digunakan.

Hasil data dari uji kelompok besar Mengacu pada segi kejelasan, kegunaan, kemudahan, kemenarikan serta kesesuaian, sehingga didapatkan analisis data yang dipaparkan melalui produk pengembangan perangkat pembelajaran gerak dasar lempar berbasis aplikasi articulate storyline dan disajikan di bawah 
Tabel 9. Hasil Analisis Data Uji Kelompok Besar Kelompok Kerja Guru (KKG) PJOK SD

\begin{tabular}{clrc}
\hline No. & \multicolumn{1}{c}{ Aspek } & \% & Kategori \\
\hline 1 & Kejelasan & 83 & Sangat Valid \\
2 & Kemudahan & 83 & Sangat Valid \\
3 & Kemenarikan & 82 & Sangat Valid \\
4 & Kesesuaian & 82 & Sangat Valid \\
5 & Kegunaan & 88 & Sangat Valid \\
\hline \multicolumn{2}{l}{ Rata-Rata } & $\mathbf{8 4}$ & Sangat Valid \\
\hline
\end{tabular}

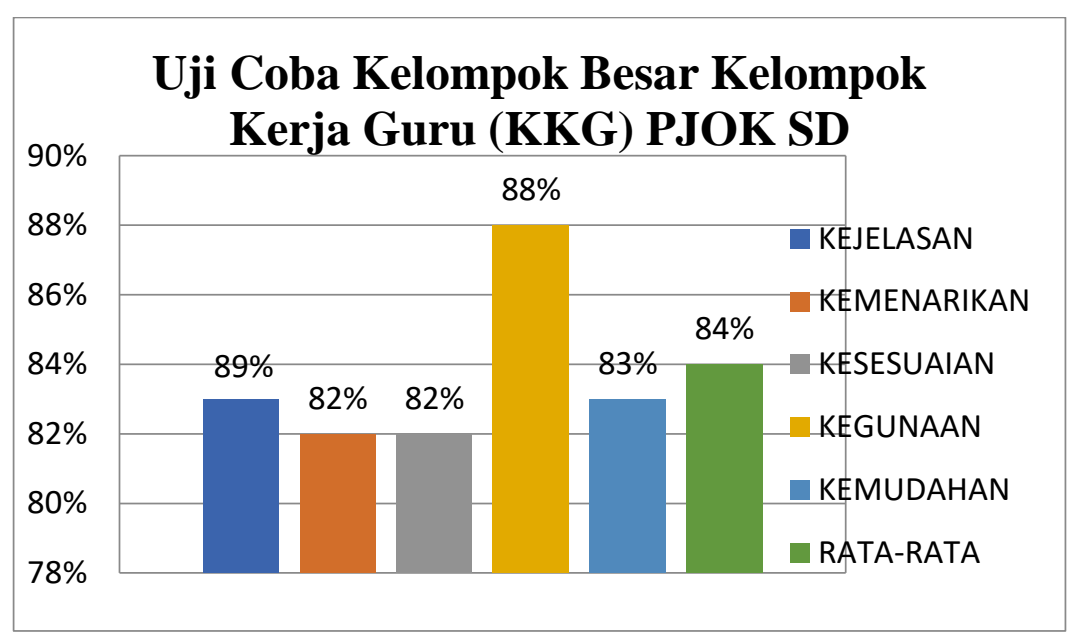

Gambar 7. Diagram Persentase Hasil Data Uji Kelompok Besar Kelompok Kerja Guru (KKG)

Berdasarkan hasil analisis data yang diperoleh dari uji coba kelompok besar oleh Kelompok Kerja Guru (KKG) PJOK SD di Kecamatan Wajak Kabupaten Malang dengan persentase sebesar 84\%, hasil tersebut didapatkan berdasarkan aspek-aspek kemudian hasil tersebut dikonversikan berdasarkan tabel klasifikasi kelayakan menunjukkan bahwa produk pengembangan perangkat pembelajaran gerak dasar lempar berbasis aplikasi articulate storyline telah memenuhi kriteria sangat valid dan layak digunakan.

\subsection{Pembahasan}

Produk pengembangan ini merupakan pengembangan perangkat pembelajaran gerak dasar lempar berbasis aplikasi articulate storyline yang terdapat: video, teks, dan suara, sehingga aplikasi articulate storyline ini masuk kedalam suatu media pembelajaran yang berpengaruh positif sebagai sarana dalam menyampaikan pembelajaran di sekolah. Media pembelajaran menggunakan software ini tidak kalah menarik dengan media interaktif lainnya Purnama, (2014). Menurut Sapitri, D, Bentri, A, (2020) menjelaskan bahwa articulate storyline sebuah perangkat yang beroleh dipakai untuk menyusun presentasi. Memegang kedudukan yang sama dengan microsoft power point, articulate storyline terdapat keunggulan presentasi yang lebih komprehensif dan kreatif. Software ini juga mempunyai fitur seperti timeline, movie, picture, character dan lain lain yang mudah digunakan. articulate storyline merupakan salah satu multimedia authoring tools yang bisa dipakai untuk menciptakan perangkat pembelajaran yang saling berinteraksi dengan isi yang dibentuk dari gabungan teks, gambar, grafik, suara, animasi, dan video. Hal tersebut selaras dengan Arwanda, P., Irianto, S., \& Andriani, (2020) 
menyatakan media pembelajaran articulate storyline merupakan salah satu media pembelajaran yang sengaja dibuat untuk mengemas sebuah pembelajaran, pemanfaatan articulate storyline sebagai media pembelajaran melibatkan peserta didik langsung, sehingga peserta didik akan terlibat aktif dalam pembelajaran. Sehingga aplikasi articulate storyline ini masuk kedalam suatu media pembelajaran yang berpengaruh positif sebagai sarana dalam menyampaikan pembelajaran di sekolah, yang nantinya produk pengembangan perangkat pembelajaran gerak dasar lempar berbasis aplikasi articulate storyline ini berupa perangkat pembelajaran dalam bentuk aplikasi android yang pastinya menarik dan dapat dibawa kemana saja. Leow, \& Neo, (2014), menyatakan bahwa pembelajaran yang dilakukan secara inovatif, salah satunya dengan memanfaatkan konten media pembelajaran yang dapat melibatkan siswa, tanpa disadari akan meningkatkan motivasi dan semangat siswa dalam proses pembelajaran yang tentunya akan sangat membantu dan berpengaruh pada hasil belajar siswa. Hal tersebut sependapat dengan Kurniawan \& Tangkudung, (2017), mengatakan pembelajaran adalah suatu kegiatan pendidik untuk menyampaikan pesan atau materi kepada siswa, pembelajaran akan semakin menarik anak untuk aktif dalam kegiatan pembelajaran pendidikan jasmani menggunakan berbagai variasi dalam pembelajaran. Pembelajaran ini bertujuan agar siswa nantinya mendapatkan berbagai pengalaman, pengetahuan, nilai, ketrampilan, serta norma yang berfungsi untuk kehidupan yang lebih baik. Sehingga aplikasi articulate storyline ini termasuk dalam media yang memiliki pengaruh positif sebagai media dalam kegiatan proses pembelajaran di sekolah. Apalagi bentuk akhir dari pada produk pengembangan pengembangan perangkat pembelajaran gerak dasar lempar berbasis aplikasi articulate storyline ini berupa aplikasi articulate storyline yang dikemas dalam bentuk aplikasi android yang tentunya sangat menarik dan mudah untuk dibawa kemana-mana. Menurut Nugraheni (2017) Dengan menggunakan media pembelajaran interaktif menggunakan Articulate Storyline, siswa mendapatkan gambaran materi sangat jelas karena di dalamnya terdapat materi yang dikemas berupa teks, gambar, animasi, audio, dan video. Produk pengembangan ini selain berbasis aplikasi articulate storyline juga ditekankan pada materi pembelajaran gerak dasar lempar kelas IV yang dikemas dalam video materi pembelajaran. Produk ini juga dapat dijadikan sebagai bahan ajar pembelajaran didalam kelas sebelum dipraktikkan di kegiatan inti pembelajaran di lapangan. Terdapat 5 video materi inti pembelajaran didalam produk pengembangan pembelajaran gerak dasar lempar berbasis aplikasi articulate storyline ini. Dalam video materi yang digunakan dalam pembelajaran gerak dasar lempar berbasis aplikasi articulate storyline ini dapat membantu guru pendidikan jasmani dan kesehatan dalam memberikan materi gerak dasar lempar dikarenakan materi yang termuat dalam aplikasi articulate storyline ini mengandung materi penunjang untuk meningkatkan keterampilan gerak dasar lempar. Articulate Storyline dapat menciptakan kelas yang unik dan dapat mengajak siswa untuk aktif dalam pembelajaran karena materi dilengkapi kuis yang dapat langsung dikerjakan dan tanpa menunggu koreksi jawaban dari guru, sebab skor telah otomatis muncul dari sistem. Aplikasi articulate storyline ini berisi rencana pelaksanaan pembelajaran gerak dasar lempar kelas IV, materi pembelajaran kelas IV meliputi: pengertian gerak dasar lempar, sarana dan prasarana gerak dasar lempar, teknik dasar lempar, serta video pembelajaran materi kelas IV, terdapat evaluasi penilaian untuk kelas IV, serta biodata peneliti. Diharapkan dalam pembelajaran gerak dasar lempar lebih bervariasi sehingga dapat meningkatkan minat peserta didik serta menambah referensi guru dalam proses pembelajaran mata pelajaran pendidikan jasmani dan kesehatan terutama pembelajaran gerak dasar lempar kelas IV. Berdasarkan hasil uji validasi ahli pembelajaran diperoleh persentase sebesar 87\%, hasil uji validasi ahli permainan Sekolah Dasar diperoleh persentase sebesar 
86\%, hasil uji validasi ahli Pendidikan Jasmani, Olahraga dan Kesehatan diperoleh persentase sebesar $83 \%$, hasil uji validasi ahli media diperoleh persentase sebesar 96\%, hasil uji validasi ahli atletik diperoleh persentase sebesar 94\%, hasil uji coba kelompok kecil diperoleh persentase sebesar $86 \%$, hasil uji coba kelompok besar diperoleh persentase sebesar $84 \%$, dan artinya keseluruhan hasil uji validasi oleh beberapa ahli dan saat uji coba produk pada kelompok kecil serta kelompok besar untuk produk articulate storyline mendapatkan hasil kriteria sangat valid dan layak digunakan

\section{Simpulan}

Dari hasil pengembangan dan penelitian produk pembelajaran gerak dasar lempar berbasis aplikasi articulate storyline, maka dapat disimpulkan bahwa produk pengembangan gerak dasar lempar berbasis aplikasi articulate storyline layak digunakan dalam pembelajaran gerak dasar lempar untuk kelas IV dan dapat dijadikan sebagai penunjang pembelajaran pada mata pelajaran PJOK kelas IV untuk materi pembelajaran gerak dasar lempar.

\section{Daftar Rujukan}

Akbar, R. A., \& Hariyanto, E. (2020). Pengembangan Bahan Ajar Pencak silat Untuk Siswa Sekolah Dasar. Sport Science and Health, 2(7), 350-356. http://journal2.um.ac.id/index.php/jfik/index

Akhmad, I. (2016). Sumber Belajar Penunjang PLPG 2016.

Arwanda, P., Irianto, S., \& Andriani, A. (2020). Pengembangan Media Pembelajaran Articulate Storyline Kurikulum 2013 Berbasis Kompetensi Peserta Didik Abad 21 Tema 7 Kelas Iv Sekolah Dasar. AlMadrasah: Jurnal Pendidikan Madrasah Ibtidaiyah, 4(2), 193.

Kartowagiran, B. (2015). Kinerja Guru Profesional (Guru Pasca Sertifikasi). Jurnal Cakrawala Pendidikan, 3(3), 6-26. https://doi.org/10.21831/cp.v3i3.4208

Kurniawan \& Tangkudung. (2017). Development Of Interactive Multimedia-Based Gymnastics Floor Techniques Learning Model For Junior High School Students. Jipes-Journal of Indonesian Physical Education and Sport, 3(1), 100.

Larsson, H., \& Karlefors, I. (2015). Physical education cultures in Sweden : fitness, sports , dancing, learning. Journal Sport, Education and Society, 20(5), 573-587.

Leow, F,T, Neo, M. (2014). Interactive Multimedia Learning : Innovating Classroom Education In A Malaysian University. Journal Of Educational Technology 13(2), 99-100.

Mashudi, A. R., \& Nurrochmah, S. (2020). Survei Gerak Dasar Lokomotor dan Manipulatif Siswa Kelas IV SD. Sport Science and Health, 2(8), 415-421.

Mcneil, S. (2015). Visualizing Mental Models : Understanding Cognitive Design And Development. Journal Educational Technology Research And Development, 63(1), 73-96.

Mislan, \& Santoso, D. A. (2019). Peran Pengembangan Media Terhadap Keberhasilan Pembelajaran PJOK di Sekolah. Prosiding Seminar Nasional IPTEK Olahraga, 12-16. https://ejournal.unibabwi.ac.id/index.php/semnassenalog/article/view/585

Mustafa, P.S. \& Dwiyogo, W.D. (2020). Kurikulum Pendidikan Jasmani, Olahraga, dan Kesehatan di Indonesia Abad 21. Jurnal Riset Teknologi Dan Inovasi Pendidikan (JARTIKA) 3(2), 422-438.

Mylsidayu, A. (2014). Jurnal olahraga pendidikan. Jurnal Olahraga Pendidikan, 1(3), 32-46.

Nugraheni, T. D. (2017). Pengembangan Media Pembelajaran Interaktif Menggunakan Articulate Storyline Pada Mata Pelajaran Sejarah Indonesia Kelas X Di Smk Negeri 1 Kebumen.

Purnama, S. I, Asto, I. G. P. B. (2014). Pengembangan Media Pembelajaran Interaktif Menggunakan Software Articulate Storyline Pada Mata Pelajaran Teknik Elektronika Dasar Kelas X Tei 1 Di Smk Negeri 2 Probolinggo. Jurnal Pendidikan Teknik Elektro. 3(2), 257-279.

Purnama, \& A. (2014). Pengembangan Media Pembelajaran Interaktif Menggunakan Software Articulate Storyline Pada Mata Pelajaran Teknik Elektronika Dasar Kelas X Tei 1 Di Smk Negeri 2 Probolinggo, 3.

Sapitri, D, Bentri, A. (2020). Pengembangan Media Pembelajaran Berbasis Aplikasi Articulate Storyline Pada Mata Pelajaran Ekonomi Kelas X SMA. Jurnal Inovtech 2(1). 
Sport Science and Health, 3(7), 2021, 543-555

Wiarto, G. (2015). Inovasi Pembelajaran Dalam Pendidikan Jasmani. 